\title{
MANIFESTASI ATIPIKAL DENGUE YANG HARUS DI WASPADAI SAAT BEPERGIAN KE DAERAH ENDEMIS
}

\author{
W. N. Ayusfaiezan \\ Fakultas Kedokteran Universitas Udayana \\ (one_ayus@yahoo.com)
}

\section{Abstract}

Dengue (dengue fever/ dengue hemorrhagic fever (DHF)) is disease with high morbidity and mortality among children and adults especially in tropical countries. All people can be infected especially who live in endemic areas such as in South Asia, West and East Africa. For people outside these areas, they are not excluded from getting this disease as they can get it when they travel to endemic areas and they can even transmitted, eventhough quite rare, it to other people when they return to their countries if they are not monitored and get treatment early and properly. In order for them to be able to know when to search for help, they should know some signs, symptoms or manifestations of the disease. Not only that, they also can search for any information about any atypical or uncommon manifestations that could occur with this infection as precaution. So, this review will compiles some atypical manifestations of dengue so it can be some help for people who need it for their health, especially for their preparation before travelling to endemic areas.

Keywords: dengue, dengue fever, dengue hemorrhagic fever, endemic areas, atypical/ uncommon manifestations.

\begin{abstract}
Abstrak
Dengue (demam berdarah / berdarah dengue (DBD) adalah penyakit dengan morbiditas dan mortalitas yang tinggi di kalangan anak-anak dan orang dewasa terutama di negara-negara tropis. Semua orang dapat terinfeksi terutama yang tinggal di daerah endemik seperti di Asia Selatan, Afrika Timur dan Afrika barat. Bagi orang yang tinggal di luar daerah ini, mereka tidak dikecualikan dari mendapatkan penyakit ini karena mereka bisa mendapatkannya ketika mereka melakukan perjalanan ke daerah endemik dan ianya bahkan dapat ditransmisikan, walaupun cukup jarang berlaku, kepada orang lain ketika mereka kembali ke negara mereka jika mereka tidak diawasi dan mendapatkan pengobatan dini dan tepat. Agar mereka bisa tahu kapan untuk mencari bantuan, mereka harus tahu beberapa tanda-tanda, gejala atau manifestasi dari penyakit ini . Bukan hanya itu, mereka juga bias mencari informasi mengenai manifestasi atipikal atau tidak umum yang bisa terjadi dengan infeksi ini supaya mereka dapat lebih berhati-hati. Jadi, ulasan ini akan mengkompilasi beberapa manifestasi atipikal dari demam berdarah sehingga dapat memberi bantuan untuk orang- orang yang membutuhkannya demi kesehatan mereka, terutama untuk persiapan mereka sebelum bepergian ke daerah endemis.
\end{abstract}

Kata Kunci: dengue, demam dengue,demam berdarah dengue, daerah endemik, manifestasi atipikal/ tidak lazim.

\section{PENDAHULUAN}

Laporan pertama epidemi tentang kemungkinan akan dengue terjadi di tiga benua (Asia, Afrika, dan Amerika Utara) pada tahun 1779 dan 1780. Saat ini, dengue terjadi di seluruh dunia, dengan daerah endemis yang sudah dikenal Asia tropis, Polynesia, Mikronesia dan Timur dan Afrika Barat. Dalam beberapa tahun terakhir, telah terjadi suatu peningkatan dengue di Amerika Selatan dan Tengah, Karibia dan India. Penyebaran sebagian besar melalui manusia-nyamuk-manusia, dengan viremia persisten pada manusia memmungkinkan nyamuk menginfeksi. Flavivirus merupakan penyebab yang paling umum dan menyebabkan $<100$ juta infeksi per tahun. Di masa depan wabah bisa terjadi karena ada vektor potensial lain A aegypti dan albopictus A, di pesisir selatan Amerika Serikat ${ }^{6}$.

\section{DENGUE}

Dengue adalah penyakit virus yang dijumpai di daerah beriklim tropis dan subtropis di seluruh dunia, disebabkan oleh virus yang dibawa oleh nyamuk Aedes dengan gejala termasuk sakit kepala berat, nyeri punggung dan sendi, demam tinggi, ruam, kemerahan 
pada wajah dan kongesti bola mata. Tahap pertama sering berlangsung selama dua atau tiga hari, diikuti oleh hilangnya gejala, tapi kemudian diikuti dengan munculnya kembali gejala selama dua atau tiga hari. Sedangkan, demam berdarah dengue adalah sekuel serius dengue reguler, ditandai dengan gambaran hemoragik seperti trombositopenia dan hemokonsentrasi. Manusia terinfeksi dengan virus dengue dengan gigitan nyamuk A.aegypti yang terinfeksi. A aegypti berukuran kecil, hitam dan- putih, banyak dijumpai di daerah perkotaan yang lebih suka bertelur di wadah buatan umumnya ditemukan di dalam dan sekitar rumah di daerah tropis. Sebagai contoh, vas bunga, ban mobil tua, ember yang mengumpulkan air hujan, dan sampah adalah tempat yang sangat cocok untuk bertelur. Wadah yang digunakan untuk penyimpanan air, khususnya drum 55 galon dan tangki semen, sangat penting dalam memproduksi sejumlah besar nyamuk dewasa di dekat tempat tinggal di mana orang tinggal dan bekerja.

Nyamuk dewasa lebih memilih berada di dalam ruangan, yang tidak mengganggu, dan lebih memilih untuk makan pada siang hari. Nyamuk betina berperilaku berbeda, proses makannya akan terganggu hanya dengan sedikit gerakan, dan akan kembali ke orang yang sama atau orang yang berbeda untuk melanjutkan proses makan. Karena perilaku ini, $A$ aegypti betina akan sering makan pada beberapa orang dalam satu periode dan, jika infektif, mungkin menularkan virus dengue ke beberapa orang dalam waktu singkat. Hal ini membuat mereka vector yang sangat efektif, beberapa anggota rumah tangga yang sama dapat menjadi terjangkit demam berdarah dalam jangka waktu 24- 36 jam, mengindikasikan transmisi oleh nyamuk infektif tunggal. Mereka sulit untuk dikendalikan penduduk di daerah tropis jarang menyadari kehadiran nyamuk ini. Setelah seseorang digigit oleh nyamuk yang infektif, virus mengalami masa inkubasi 3 sampai 14 hari (rata-rata, 4 sampai 7 hari), setelah itu orang tersebut bisa mengalami onset akut demam disertai berbagai tanda dan gejala nonspesifik. Selama periode demam akut ini, yang mungkin sesingkat 2 hari dan selama 10 hari, virus dengue dapat bersirkulasi dalam darah perifer. Jika $A$ aegypti lainnya menggigit orang yang sakit selama tahap viremic demam ini, nyamuk tersebut dapat terinfeksi dan kemudian menularkan virus ke orang lain yang sebelumya tidak terinfeksi, setelah masa inkubasi ekstrinsik dari 8 sampai 12 hari.

Infeksi ini menimbulkan serangkaian spektrum penyakit, mulai dari tak terlihat atau demam ringan sampai keadaan hemoragik yang berat dan fatal. Infeksi dengan keempat serotipe menyebabkan manifestasi klinis yang serupa dan mungkin bervariasi dalam frekuensi dan tingkat keparahan. Masa inkubasi bervariasi dari 3 sampai 14 hari (rata-rata, 4 sampai 7 hari). Di daerah endemik demam berdarah-, terutama untuk anak-anak, infeksi dengue seringkali tidak spesifik secara klinis, dengan gejala sindrom virus yang memiliki berbagai nama lokal. Faktor risiko penting yang mempengaruhi proporsi pasien untuk memiliki penyakit yang parah selama transmisi epidemi adalah strain dan serotipe virus yang menginfeksi, status imun indivisu, usia pasien, dan latar belakang genetik dari host manusia.

$\underline{\text { AGEN }}$

Ada empat serotipe virus dengue: DENV-1, DENV-2, DENV-3, dan DENV-4. Semuanya berasal dari genus Flavivirus, famili Flaviviridae (jenis spesies virus demam kuning), yang berisi sekitar 70 virus. flavivirus relatif kecil (40-50 nm), RNA beruntai tunggal dan sferis. Genom flavivirus sekitar 11.000 basis dan terdiri dari tiga struktur dan tujuh protein non-struktural.

Ada tiga sub kelompok utama dalam famili ini: tick-borne, nyamuk, dan virus tanpa vektor arthropoda yang dikenal. Virus dengue membentuk kompleks dalam subkelompok nyamuk. Semua flaviviruses memiliki epitop kelompok umum pada protein envelop yang menghasilkan lintas-reaksi dalam tes serologi. Hal Ini membuat diagnosis serologi infeksi flavivirus sulit. Hal ini terutama berlaku pada empat virus dengue. Infeksi dengan satu serotipe dengue memberikan kekebalan seumur hidup terhadap virus itu, tetapi tidak terhadap serotipe lainnya. Dengan demikian, orangorang yang tinggal di daerah endemik dapat terinfeksi dengan tiga, dan mungkin empat. ${ }^{8}$

\section{$\underline{\text { MANIFESTASI KLINIS }}$}

Infeksi virus dengue dapat asimtomatik atau dapat menyebabkan demam (sindrom virus), demam berdarah (DD), atau demam berdarah dengue (DBD) termasuk dengue shock syndrome (DSS). Infeksi dengan satu serotipe dengue biasanya memberikan kekebalan seumur hidup dengan serotipe tertentu selain kekebalan parsial terhadap virus dengue serotipe lain untuk sementara waktu. Manifestasi klinis tergantung pada strain virus dan faktor host seperti usia, jenis kelamin dan status imunitas, seperti disebutkan sebelumnya. ${ }^{5}$

Infeksi dengue dapat asimtomatik atau berhubungan dengan penyakit nonspeficic atau dengan dengue klasik setelah masa inkubasi 5-6 hari. Terdiri dari demam, ruam eritematosa dan mialgia berat yang melibatkan punggung, kepala, otot dan sendi juga. Suhu tinggi pasien biasanya kembali normal setelah 1-2 hari demam dan ruam, tetapi akan kembali 3-4 hari kemudian. Kembalinya demam diikuti dengan ruam yang melibatkan wajah, badan dan tungkai, telapak tangan dan kaki dikecualikan. ${ }^{6}$ 
Antara dua periode demam, pasien mengalami gejala-gejala gastrointestinal atau gejala pernapasan atau keduanya. Limfadenopati generalisata sering ada. Resolusi terjadi pada minggu kedua, dan kematian sangat langka. Pada rechallenge dengan strain yang terkait, demam berdarah dapat menyebabkan penyakit hemoragik yang berat dan shock (DHF / DSS), yang terjadi pada puluhan hingga ratusan ribu kasus per tahun. Gejala syok hemorrhagic yang dikaitkan dengan rupturr pembuluh darah, perdarahan internal dan hilangnya plasma. Selain itu, ada demam tinggi, mual atau muntah, ecchymosis dan edema tangan. ${ }^{6}$

\section{MANIFESTASI ATIPIKAL}

Selain manifestasi klinis seperti yang disebutkan sebelumnya, ada beberapa manifestasi atipikal atau yang tidak biasa pada dengue, DHF atau DSS. Termasuk trombositopenia berkepanjangan, nyeri perut akut, perdarahan berat gastro-intestinal, penurunan kesadaran, ensefalitis, gagal hati, ikterus obstruktif, peningkatan enzim hati, sindrom Reye, gagal ginjal akut dan Koagulasi Intravaskular Diseminata (DIC).

Seperti kita ketahui, trombositopenia biasanya terlihat hanya selama beberapa hari, lima atau enam hari. Namun, dalam beberapa kasus atipikal, trombositopenia dapat menetap dan berlangsung selama satu bulan seperti yang dilaporkan oleh Kamil et al. Dalam kasusnya, pasien sebenarnya sudah pulih, sehingga beberapa kemungkinan dipertimbangkan seperti infeksi bakteri selama fase pemulihan yang menyebabkan sepsis. Selain itu, juga terdapat kemungkinan adanya gangguan trombosit. Tapi, setelah di follow up sepsis negatif dan pasien juga sembuh spontan, kemungkinan tadi menjadi tidak masuk akal dan memungkinkan penyebabnya adalah Gangguan hati dan disfungsi neurologis juga telah diklasifikasikan sebagai manifestasi atipikal DBD. Ensefalopati pada DBD adalah manifestasi atipikal dan mungkin muncul dalam berbagai bentuk, termasuk penurunan sensivitas, kejang, leher kaku, tanda-tanda piramidal, sakit kepala, edema papil, mioklonus dan gangguan perilaku. Sequela pasca-infeksi terutama amnesia, demensia, psikosis, sindrom Reye dan meningoensefalitis. Untuk anak-anak dengan DSS, gangguan neurologik tidak hanya disebabkan oleh hipoperfusi serebral atau perdarahan intrakranial, tetapi juga dapat disebabkan oleh edema serebral, anoksia serebral, gagal ginjal, pelepasan produk toksik, efek neurotropik langsung virus dengue yang menyebabkan ensefalitis / encelopathy, atau bahkan akibat sekunder dari disfungsi hati dan gangguan metabolisme seperti hipoglikemia dan hyponatremia. Secara patofisiologi, terdapat faktor termasuk lesi suatu strain yang tidak biasa atau bermutasi dari virus dengue atau pasien memperoleh infeksi lain virus dengue dengan strain yang berbeda selama fase pemulihan. $^{3}$

Seperti disebutkan sebelumnya, gangguan jantung juga merupakan salah satu manifestasi atipikal dengue. Disfungsi jantung dapat mempersulit pengelolaan hipotensi dalam DSS. Ada satu laporan dari Singapura tentang dengue miokarditis / perikarditis yang sangat jarang, di mana PL Goh menjelaskan tentang fungsi jantung pasien mereka yang secara signifikan terganggu dengan fraksi ejeksi rendah (EF). Ini mempengaruhi keparahan dan menyebabkan respon negatif terhadap resusitasi cairan dan dukungan inotropik. Kadar CK-MB dan troponin T juga meningkat dan tentu saja berakibat fatal. ${ }^{1}$

Ada juga disfungsi diastolik yang kemungkinan disebabkan oleh edema miokard dalam pengaturan anasarca. Anak-anak dengan masalah ini memiliki risiko lebih tinggi terkena peningkatan tekanan pengisian ventrikel kiri dan edema paru. Sebuah studi profil hemodinamik pada DBD dari Thailand juga melaporkan penurunan indeks jantung karena fraksi ejeksi menurun dan menurunkan preload dan adanya laporan dari New Delhi tentang hypokinesia global. ${ }^{2}$

Lalu, ada sindrom kompartemen abdomen (ACS). Merupakan distensi abdomen dengan tekanan intra-abdomen (IAP)> $15 \mathrm{~mm} \mathrm{Hg}$, disertai dengan setidaknya dua hal berikut: oliguria atau anuria; dekompensasi pernapasan; hipotensi atau syok; asidosis metabolik. Untuk pasien yang memiliki DSS tidak stabil dengan syok refrakter dan kelebihan cairan, mereka memiliki manifestasi klinis diatas. Ketika hipertensi intra-abdominal tinggi teratasi, hal ini dapat berkontribusi untuk meningkatkan fungsi kardiorespirasi kecuali ada komplikasi lain. ${ }^{2}$

jaringan langsung yang disebabkan oleh virus karena neurotropicity, perdarahan kapiler, koagulasi intravaskular diseminata dan gangguan mentabolik virus dengue yang diobservasi dalam cairan serebrospinal (CSF) di salah satu studi, menunjukkan bahwa virus telah melewati sawar darah-otak dan langsung menyerang otak. Dalam hal ini, serotipe dengue 2 dan 3 telah menjadi penyebab utama gejala. Selain gangguan neurologis, terdapat laporan mengenai Acute Disseminated Encephalomyelitis (ADEM) yang memperburuk status neurologis karena ada disfungsi sawar darah-CSF. Hal ini dapat terjadi karena berbagai exanthema virus dan sindrom Guillain Barre, yang terlihat pada anak-anak India setelah infeksi dengue dengan keterlibatan materi abu-abu (grey matter) yang dominan. Namun, pada orang dewasa, demam berdarah yang menyebabkan ADEM sangat jarang. ${ }^{2,8}$ 
Manifestasi Atipikal Infeksi Dengue

Sistem

\section{Gastrointestinal}

Kardiovaskuler

Respirasi

\section{Neurologi}

Ginjal

Limfo-retikular

Muskuloskeletal

\section{Manifestasi}

Kolesistitis akalkulus, pankreatitis akut, parotitis akut, diare, hepatitis/gagal hati fulminan

\section{Gangguan Konduksi}

Blok atrioventrikular, disfungsi sinus node, atrial fibrilasi, Miokarditis, perikarditis

ARDS (Acute Respiratory Distress Syndrome), perdarahan pulmonal

Ensefalopati, ensefalitis, meningitis septik, perdarahan intrakranial, trombosis, mononeuropati, polineuropati, Sindrom Guillian Barre, myelitis

Anemia Hemolitik, gagal ginjal

Ruptur limpa spontan, infeksi KGB, hemofagositosis

Myositis, rhabdomyolisis

Tabel 1

Disfungsi hati disebabkan berbagai faktor karena ada banyak penyebab seperti syok berkepanjangan, asidosis metabolik dan DIC dengan hepatitis iskemik yang akan mempengaruhi hati, yang juga merupakan tempat utama replikasi virus dengue. Antigen virus dengue ditemukan dalam sel-sel Kupfer dan sinusoid hati yang menunjukkan bahwa hepatosit dapat mendukung replikasi virus. Manifestasi hati dapat ditandai dengan hepatitis akut dengan nyeri pada hypokondrium, hepatomegali, ikterus dan peningkatan kadar aminotransferase. Pada hepatitis kadar puncak enzim tersebut pada hari kesembilan setelah timbulnya gejala dan secara bertahap kembali ke kadar normal dalam waktu 3 minggu. Temuan histopatologi termasuk nekrosis centrilobular, perubahan lemak, hiperplasia sel Kupfer, tubuh asidofil dan perubahan monosit pada jalur portal. Ikterusmungkin disebabkan oleh banyak faktor seperti agresi hati yang disebabkan oleh virus dengue dan / atau hipoksia dan iskemia jaringan dalam kasus syok. ${ }^{2,8}$

Pankreatitis akut merupakan manifestasi yang jarang pada demam dengue seperti yang dilaporkan sebelumnya hanya dalam beberapa kasus. Keterlibatan Pankreas mungkin karena invasi langsung virus atau akibat hipotensi pada DBD. Meskipun tidak ada laporan temuan histologis pankreas pada infeksi dengue karena sulit untuk mendapatkan sampel, pemeriksaan sonografi dapat menunjukkan pankreas membesar dan meningkatkan amilase dan lipase serum. Dalam satu kasus yang dilaporkan oleh Wijekoon et al, dan merupakan yang pertama dari Sri Lanka dan di Asia Selatan, gejala pankreatitis akut mendominasi ketika pasien datang ke rumah sakit dengan "bedah perut akut", hipotensi dan hiperglikemia adalah presentasi awal. Pasien juga memiliki jumlah trombosit yang rendah, riwayat demam dan hepatomegali dengan ketinggian moderat transaminase, semuanya mengindikasikan DBD. ${ }^{4,8}$

Kolesistitis akalkulus juga merupakan manifestasi yang jarang pada demam dengue. Pasien mungkin datang dengan demam, nyeri perut kuadran kanan atas, tanda Murphy positif, tes fungsi hati yang abnormal, dan USG perut menunjukan distensi kandung empedu, nyeri lokal, lumpur fluidand pericholecystic menebalkan dinding kandung empedu tanpa batu. Meskipun patogenesis yang tepat dari kolesistitis acalculous tidak diketahui, tetapi puasa yang berkepanjangan, spasme ampula Vater, infeksi, endotoksemia, microangiopati dan cedera iskemia reperfusi adalah satu di antara kemungkinan penyebab kolestasis dan peningkatan viskositas empedu. Namun, dalam demam berdarah, perubahan patofisiologi utama terjadi karena peningkatan permeabilitas pembuluh darah yang menyebabkan kebocoran plasma dan efusi serosa dengan kandungan protein yang tinggi dan menyebabkan penebalan dinding kandung empedu yang menyebabkan masalah motilitas. Ada 
hubungan yang signifikan antara penebalan dinding kandung empedu dan keparahan serta perkembangan demam berdarah. Kolesistektomi tidak disarankan karena perjalanan penyakit ini biasanya sembuh sendiri dan ketebalan dinding kandung empedu biasanya kembali normal. ${ }^{8,9}$

\section{KESIMPULAN}

Dengue dapat menimbulkan spektrum besar manifestasi, baik umum maupun atipikal, tidak mengatakan presentasi multisistemik juga. Oleh karena itu, hal terbaik yang dapat dilakukan adalah setidaknya mengenal berbagai manifestasi itu demi diri kita sendiri. Hal ini juga menyimpulkan bahwa manifestasi atipikal berkaitan dengan keterlibatan berbagai organ, termasuk hati, jantung, sistem saraf pusat yang menyebabkan manifestasi klinis yang berat dan bahkan letal, di antaranya miokarditis dan hepatitis. Kasuskasus ini harus menjadi perhatian bagi dokter dan para professional di bidang kesehatan dalam pendekatan awal pasien untuk mencapaipengobatan yang lebih baik.

\section{REFERENSI}

1. PL Goh. Dengue perimyocarditis : a case report. Hong Kong j. emerg. med. Jan 2010; Vol. 17(1):58-60.

2. Shrishu R. Kamath, Suchitra Ranjit. Clinical Features, Complications and Atypical Manifestations of Children with Severe forms of Dengue Hemorrhagic Fever in South India. Indian Journal of Pediatrics Oct 2006; Vol. 73: 889-895.

3. Kamil SM, Mohamad N H, Narazah M Y, Khan F A. Dengue Hemorrhagic Fever with Unusual Prolonged Thrombocytopaenia. Singapore Med J 2006; 47(4): 332-334.

4. CN Wijekoon and PWMCSB Wijekoon. Dengue Hemorrhagic Fever Presenting with Acute Pancreatitis. July 2010; Vol. 41(4): 864-866.

5. World Health Organization. Comprehensive Guidelines for Prevention and Control of Dengue and Dengue Hemorrhagic Fever. Revised and Expanded Revision. WHO; 2011.

6. Walter R. Wilson, Merle A. Sande. Current Diagnosis \& Treatment in Infectious Diseases. International Edition. 2001: 463-466.

7. Sameer Gulati, Anu Maheshwari. Atypical Manifestations of Dengue. Tropical Medicine and International Health Sept 2007; Vol. 12(9): 1087-1095.

8. Vijay Kumar Aneja, Gitanjali Kochar, Neelam Bisht. Unusual Manifestations of Dengue Fever. Apollo Medicine March 2010; Vol. 7(1): 69-76.

9. Farah Hisamonie $\mathrm{KOH}$, Hartini MISLI, Vui Heng CHONG. Acute Acalculous Cholecystitis
Secondary to Dengue Fever. Brunei Int Med J. 2011; 7(1): 45-49. 